\title{
Editorial: On Variety and Tolerance ${ }^{*}$
}

\section{GERRIE F. SNYMAN (UNISA)}

Old Testament Essays (New Series) is an instrument through which scholars can publish their research in the field of the Old Testament or Hebrew Bible. Its readers are members of the Old Testament Society of South Africa, scholars in Africa, and the rest of the world interested in the Old Testament in general as well as in (South) African biblical scholarship. The primary aim of the journal is to propagate the study of the Old Testament in (South) Africa from various points of view as well as within numerous fields related to the study of the Old Testament.

In this issue, Jaco Gericke's article on philosophical criticism and the role of the analytical and continental philosophies is perhaps a good place to start, given the fact that the triennial conference of the International Organisation for the Study of the Old Testament gathers at the University of Stellenbosch this year. A variety of scholars from the entire world are expected to participate, and they most certainly will exhibit the analytical-continental divide Gericke refers to. Gericke concludes that philosophical criticism is likely to remain characterised by methodological diversity and tolerance, but he foresees problems when a scholar practices philosophical criticism on one side of the analytical-continental divide with an audience on the other side. It makes for a clash of paradigms - a clash currently unfolding in South Africa in terms of what is believed to be Western and colonial in contrast to what is regarded as decolonial. It will be interesting to see how Gericke's description becomes actualised in the South African context and whether this divide also plays a role in the current intellectual climate where various thinkers on both sides of the divide are implicated in the colonial enterprise and racism. Would African philosophical criticism pose a challenge, or would it reflect the same kind of divide?

I would refrain from categorising the current issue of Old Testament Essays in these terms, but this issue presents a variety of research on Psalms, Exodus, Proverbs, Leviticus, Esther, Daniel, and Amos from several perspectives (philosophy, hermeneutics, translation, philology, patriarchy, worker class, gender criticism, social identity and war), originating from quite a few scholars residing in South Africa, Nigeria, Ghana, France and Germany. This variety translates into a brief note in French by Bernard Gosse and a German essay on Psalms by Beat Weber with the rest of the essays in English. Of the twelve participating authors only two are women, which means that Old Tes-

\footnotetext{
To cite: Gerrie F. Snyman, "Editorial: On Variety and Tolerance," OTE 29/1 (2016): 9-10, DOI: http://dx.doi.org/10.17159/2312-3621/2016/v29n1a2
} 
tament Studies is perhaps still male dominated, given the role of patriarchy to which the article of Biwul attests.

The current issue presents the reader with four studies on Psalms. Phil Botha's article proposes that Ps 16 should be regarded as a Torah-wisdom composition which exemplifies true blessedness as in compliance with the Torah of YHWH, where the supplicant expresses a contentedness with the fate of life. In terms of time of origin and teaching, Ps 16 appears to be much closer to Ps 1 as is currently thought. Beat Weber looks at the meaning of the Psalter as a book and the importance of perceiving the individual psalms in sequence. With Psalm 18 as his point of departure, he looks at recurrences of Gattung (royal psalms) and of concepts and motifs (refuge, rescue, theophany, etcetera). On a redactional brief note, for Bernard Gosse, the use of the Psalter in Isa 12 is linked to the parallel created by the exit from Egypt and the return from the Exile. This return from the exile is permitted by the fall of Babylon and does not exclude the disappearance of the Davidic dynasty. Spangenberg compares Ps 73 with Qohelet, and he concludes that while both underwent experiences that did not accord with the traditional wisdom paradigm, they reflect differently on it.

Paul Kruger investigates a war atrocity mentioned in Amos 1:13, that is, the so-called "ripping open pregnant women." He concludes that this phrase is not so much a historical truth as it is a rhetorical device to underline the gravity of war. Matthew Michael read the books of Esther and Daniel as two opposing attitudes to the problem of Jewish identity. Whereas the book of Esther generally advocates extreme adoption of a foreign culture, the book of Daniel promotes defiance.

The next few essays endeavour to bridge the gap between an ancient text and a different later historical context. Yaw Adu-Gyamfi looks into an Achan prayer practice regarding witches on the basis of Exod 22:18. Joel Biwul questions the interpretation of the epilogue in Proverbs (ch. 31) that eulogises the outstanding qualities of the female figure. He calls attention to the male figure in some of the verses. Ndikho Mtshiselwa argues that the concern of the Holiness Code for social justice for the working-class people can throw light on the reading of ancient texts such as the Hebrew Bible, particularly from the perspective of the Latino/a biblical criticism. Such a reading has, according to him, implications for the working-class people in his country. The article of Charlene van der Walt and Judith Terblanche explores the intertextual dialogue between two seemingly distant texts, namely Exod 1-3 (with the community that formed around Moses) and the film Shirley Adams (exploring the intersectionality of poverty, violence, gender, class, race, and disability within the South African society).

Gerrie Snyman, General Editor, Old Testament Essays. Department of Biblical and Ancient Studies, Unisa. Email: snymagf@unisa.ac.za or oteeditor@otwsa-otssa.org.za. 